\title{
Perbedaan Communication Back Massage dan Back Massage dalam Menurunkan Tekanan Darah Pada Klien dengan Lansia dengan Hipertensi
}

\author{
Rizal Arifin*, Harmayetty**, Sriyono** \\ *Mahasiswa Program Studi Ilmu Keperawatan, Fakultas Keperawatan Universitas Airlangga \\ ** Staf Pengajar Fakultas Keperawatan Universitas Airlangga \\ Email: principles7nurse@gmail.com
}

\begin{abstract}
Introduction: There are many drugs in the effort to cure hypertension for the old that in fact have bad influence because they cause dependence and are risky with misestimated doses. Communication back massage and back massage are two of complementary therapies recommended to lower blood pressure due to each relaxation effects are good. This study aims to clarify the difference of communication back maassage and back massage to reduce blood pressure. Method: This study was used quasy experimental design. The total samples in this study were 14 old patients who got hypertension. They were divided into 2 groups, one of the groups was treated with communication back massage and the other one was only treated with back massage. The independent variable was communication back massage and back massage. The dependent variable was blood pressure, which was observed for 5 days. Data were collected using aneroid sphygmomanometer and observation paper then analysis was implemented using Paired t-test with level significance $\alpha \leq 0.05$ and Independent $t$-test with level significance $\alpha \leq 0.05$. Result: The result showed that blood pressure decrease in significantly both in group one and group two ( $p=0.04$ in group one and $p=0.046$ in group two). Between the group one and the group two, there was no difference on blood pressure reduction ( $p=0.315)$. Discussion: Communication back massage and back massage have a same effect on blood pressure reduction in old patient who get hipetension. The possible explanation for these findings is that communication back massage and back massage have a relaxation effect that can decrease norepinefrin, decrease $A D H$ and increase endorphine. The decrease of norepinephrine can widen blood vessel. The decrease of ADH can reduce excessive fluid in the blood circulation. The increase of endhorphine can reduce sympathetic nerve activity. Therefore, blood pressure level will be decreased.
\end{abstract}

Keywords: Therapeutic Communication, Back massage, Hypertension in the old

\section{PENDAHULUAN}

Pandangan tentang meningkatnya tekanan darah sebagai hal normal dalam proses penuaan saat ini telah disangkal dengan banyak bukti tentang dampak tekanan darah terhadap tingginya tingkat morbiditas dan mortalitas, serta fakta nyata manfaat dari pengontrolan hipertensi pada lansia (Duthie \& Katz, 2007). Banyak diantara penderita hipertensi baru ditemukan pada usia 60 tahun atau yang lebih tua sekitar 65\%, sedangkan pada dewasa ditemukan pada usia 20-39 tahun yang hanya 6,7\% (Duthie \& Katz, 2007). Lebih dari itu, data epidemiologis telah mendukung adanya peningkatan risiko penyakit kardiovaskuler, stroke dan penyakit ginjal secara terusmenerus seiring dengan level tekanan darah pada dewasa dan lansia (Duthie \& Katz, 2007). Laporan dari ACCF/AHA 2011 Expert Consensus Document on Hypertension in the Elderly terungkap bahwa jumlah pasien hipertensi dengan hipertensi sistolik terisolasi yaitu hipertensi dengan ciri khas tekanan sistolik cenderung terus naik $>140 \mathrm{mmHg}$, tekanan diastolik yang cenderung dibawah $90 \mathrm{mmHg}$ disertai tingginya tekanan nadi meningkat dengan umur, selain itu dari laporan ini juga diketahui bahwa $65 \%$ dari pasien dengan hipertensi sistolik terisolasi berusia 60-69 tahun dan lebih dari 90\% berusia >70 tahun (Aronow, 2011). Prevalensi hipertensi sistolik terisolasi 
ternyata lebih banyak wanita daripada pria, mengingat proporsi hipertensi yang diakibatkan oleh hipertensi sistolik terisolasi pada lansia sangat dipengaruhi ras dan etnis (Aronow, 2011).

Penelitian di Indonesia yang meliputi 5 Pulau Besar dan Pulau Maluku tentang jumlah penderita hipertensi sistolik terisolasi telah dilakukan, dan ditemukan bahwa dari 4.436 orang penderita hipertensi, $7,12 \%$ dari mereka ternyata menderita hipertensi sistolik terisolasi (Soejono, 2003). Data dari Dinas Kesehatan Provinsi Jawa Timur 2010 menunjukkan bahwa penderita hipertensi sistolik terisolasi di Jawa Timur mendapat urutan ke-3 terbanyak yaitu $12,4 \%$ dari total penduduk Jawa Timur sebanyak 38 Juta jiwa. Selanjutnya Data dari Dinas Kesehatan Kabupaten Blitar menunjukkan bahwa pada tahun 2010 jumlah klien lansia dengan hipertensi sistolik terisolasi juga cukup banyak yaitu dari total penduduk 130.429 jiwa diketahui $9,4 \%$ diantara mereka menderita hipertensi sitolik terisolasi, jumlah ini naik pada tahun 2011 menjadi 9,7\%. Di UPT PSLU Blitar telah diketahui dari pengambilan data awal bahwa penderita hipertensi sistolik terisolasi juga cukup tinggi yaitu dari total 55 penghuni UPT PSLU Blitar tahun 2011 usia 60-74 tahun diketahui 36 orang menderita hipertensi sitolik terisolasi, sedangkan data terbaru pada bulan Maret 2012 telah diketahui penderita hipertensi sistolik terisolasi meningkat menjadi 43 orang. Hasil wawancara langsung diketahui bahwa keluhan utama mereka ratarata adalah sakit kepala, jantung berdebar, cemas dan tanpa keluhan. Hasil pengkajian lebih lanjut ternyata telah ditemukan beberapa faktor pemicu terjadinya peningkatan tekanan darah pada lansia diantaranya ialah lingkungan yang tidak mendukung, kurangnya interaksi sosial, pertengkaran antar sesama lansia, perasaan rindu terhadap keluarga dan perasaaan sedih karena telah di telantarkan oleh keluarganya. Pada gejala penyerta hipertensi sistolik terisolasi pada lansia selain sakit kepala ternyata cukup banyak gejala lainnya yaitu cemas, berdebar, nokturia dan yang paling sering adalah tanpa gejala (Riaz, 2010).

Proses degeneratif ialah suatu hal yang identik dengan bertambahnya usia terutama pada lansia, salah satu sistem organ vital didalam tubuh yang mengalami proses degeneratif adalah sistem kardiovaskular. Pembuluh darah merupakan bagian dari sistem kardiovaskular yang sangat rentan sekali berubah akibat penuaan (Timiras, 2007). Pada lapisan intima yaitu lapisan terdalam yang terdiri dari sel endotel mengalami proses degeneratif dengan berkurangnya produksi Nitric Oxide (NO) dan Prostacyclin yang berakibat pada kekakuan arteri, mengecilnya lumen pembuluh darah dan tingginya risikoatherosklerosis (Timiras, 2007). Pada lapisan media, berkurangnya jaringan elastin, deposisi kolagen dan kalsifikasi semakin memperparah kekakuan arteri dan mengurangi elastisitas (Aronow, 2011).

Penggunaan terapi farmakologis seperti anti hipertensi telah terbukti dapat menurunkan morbiditas dan mortalitas klien lansia dengan hipertensi sitolik terisolasi pada lansia, selain itu penggunaan terapi farmokologis juga menurunkan risikountuk terjadinya komplikasi lebih lanjut (Aronow, 2011), walaupun begitu risikodari terapi anti hipertensi yang diberikan pada klien lansia dengan hipertensi sistolik terisolasi ternyata banyak sekali kerugiannya meliputi efek samping, efek ketergantungan, tingginya biaya dan masalah lain yang semakin memperberat klien lansia dengan hipertensi sistolik terisolasi (Duthie \& Katz, 2007).

Pilihan lain terapi dalam menurunkan tekanan darah yang sudah dikenal adalah yaitu Back Massage dan Communication Back Massage. Terapi Back Massage merupakan salah satu jenis terapi komplementer yang telah terbukti dapat memberikan efek relaksasi dan menurunkan tekanan darah pada penderita hipertensi dengan penurunan tekanan darah rata-rata sekitar 10,8 mmHg (Olney, 2005). Communication Back Massage merupakan terapi Back Massage yang didalamnya terdapat suatu tehnik komunikasi untuk mengetahui kebutuhan dan keinginan klien yang bertujuan untuk memberikan manfaat yang lebih luas baik dari psikis maupun fisiologis klien (Sandhu, 2010). Efek penurunan tekanan darah dari back massage didapatkan melalui peningkatan vasodilatasi pembuluh darah, mengurangi sekresi hormon katekolamin dan dapat mengurangi rasa nyeri kepala akibat hipertensi, sehingga komplikasi lebih lanjut dapat dicegah (Goat, 1994). Sebuah studi dari University of Miami dan 
Nova Southeastern University di Amerika yang mengikut sertakan 30 orang responden dengan hipertensi, ternyata telah diketahui Back Massage memiliki efek relaksasi dimana efek relaksasi ini akan menurunkan sekresi hormon stres seperti hormon katekolamin dan kortisol, yang diukur melalui saliva responden sehingga tekanan darah klien menurun (Hernandez, 2000). Communication Back Massage yaitu suatu terapi Back Massage yang didalamnya terdapat suatu tehnik komunikasi belum diketahui keefektifannya dalam menurunkan tekanan darah jika dibandingkan dengan terapi Back Massage, perbandingan untuk mengetahui perbedaan kedua jenis terapi ini perlu dilakukan karena telah diketahui dari studi longitudinal The Farmingham Study di Amerika menemukan bahwa orang-orang umur paruh baya dengan hipertensi secara signifikan memiliki tingkat kecemasan diatas rata-rata dibandingkan orang-orang dengan normotensi, peneliti ini menyarankan bahwa terapi relaksasi dan perilaku kemungkinan menjadi terapi paling efektif untuk populasi orang-orang paruh baya dengan hipertensi akibat kecemasan (Olney, 2005).

\section{BAHAN DAN METODE}

Penelitian ini menggunakan desain Quasy-Experiment, terdapat 2 kelompok yaitu kelompok pertama yang diberikan komunikasi terapeutik, serta kelompok kedua yang hanya diberikan back massage saja. Tekanan darah diobservasi sebelum dan sesudah diberikan perlakuan selama 5 hari. Penelitian ini dilaksanakan di UPT PSLU Blitar pada tanggal 27 Mei-1 Juni 2012.

$$
\text { Populasi pada penelitan ini }
$$

berjumlah 43 orang, yaitu lansia dengan Hipertensi di UPT PSLU Blitar. Proses pengambilan sampel menggunakan tehnik non probability sampling dengan metode purposive. Sampel yang digunakan dalam penelitian ini diambil dari populasi yang sudah memenuhi kriteria inklusi sebanyak 14 orang. Kriteria inklusi dalam penelitian ini antara lain: 1) lanjut usia umur 60-74 tahun yang menderita hipertensi (sesuai kriteria WHO); dan 2) tidak mendapatkan pengobatan farmakologis anti hipertensi, jamu dan obat-obat lainnya.
Variabel independen dalam penelitian ini adalah communication back massage dan back massage. Variabel dependen dalam penelitian ini adalah tekanan darah lansia. Pengukuran variabel dependen yaitu tekanan darah pada penelitian ini menggunakan sphygnomanometer aneroid dan stetoskop. Hasil dari tekanan darah dicatat dalam lembar observasi. Pemberian communication back massage mengacu pada Standar Operasional Prosedur (SOP) pemberian communication back massage, sedangkan untuk back massage sendiri mengacu pada prosedur back massage. Alat dan bahan yang dipergunakan meliputi bed massage dan minyak zaitun.

Penentuan jumlah responden berdasarkan kriteria inklusi dilakukan secara langsung saat pengukuran tekanan darah pada pengambilan data awal dan melihat secara langsung riwayat kesehatan lansia. Komunikasi terapeutik diberikan saat pemberian perlakuan dari hari pertama sampai hari kelima dimana disetiap pemberian komunikasi terapeutik pada saat fase kerja diberikan back massage. Total waktu communication back massage adalah 30 menit, dengan pembagian 20 menit untuk komunikasi terapeutik, dan 10 menit untuk back massage. Pengukuran tekanan darah diukur sebelum dan sesudah perlakuan sampai hari kelima. Data yang terkumpul kemudian dianalisis menggunakan uji statistik Paired t-test dengan tingkat kemaknaan $\alpha \leq 0,05$. Uji statistik Independent t-test dengan $\alpha \leq 0,05$ dilakukan untuk mengetahui perbedaan dari pemberian communication back massage dan back massage.

\section{HASIL}

Nilai rerata tekanan darah sistolik kelompok 1 sebelum diberi perlakuan adalah $167 \mathrm{mmHg}$ yang mengalami penurunan nilai rerata tekanan darah sistolik setelah diberikan perlakuan communication back massage menjadi $156 \mathrm{mmHg}$. Nilai rerata perubahan tekanan darah sisitolik adalah $11 \mathrm{mmHg}$. Pada kelompok 2 terdapat 6 lansia yang mengalami penurunan tekanan darah sistolik setelah diberikan back massage saja selama 5 hari berturut-turut. Nilai rerata tekanan darah sistolik kelompok pembanding sebelum 
diberi perlakuan adalah $155 \mathrm{mmHg}$ yang mengalami penurunan nilai rerata tekanan darah sisitolik setelah diberikan perlakuan menjadi $146 \mathrm{mmHg}$. Nilai rerata penururnan tekanan darah sistolik adalah $9 \mathrm{mmHg}$. Uji statistik Paired t-test menunjukkan ada perbedaan signifikan antara sebelum dan sesudah pemberian terapi pada kedua kelompok, pada kelompok $1 \mathrm{p}=0,04$ dan pada kelompok $2 \mathrm{p}=0,046$. Pada uji statistik Independent $t$-test tidak ada perbedaan yang signifikan dalam penurunan tekanan darah antara kedua kelompok $\mathrm{p}=0,315$.

\section{PEMBAHASAN}

Hipertensi pada lanjut usia disebabkan oleh banyak faktor yang erat kaitannya dengan proses menua (aging process). Ketika usia >64 tahun, wanita diketahui cenderung mempunyai tekanan darah lebih tinggi daripada laki-laki dengan usia yang sama, hal ini sering dikaitkan dengan semakin berkurangnya hormon seks wanita yang jumlahnya terus menurun setelah masa menopause dimana telah diketahui bahwa hormone seks wanita seperti estrogen bertanggung jawab dalam mengurangi mencegah kekakuan arteri, endothelial dysfunction dan penumpukan lemak dalam darah (Aronow, 2011). Saat lansia juga sering dijumpai perubahan curah jantung, bradikardi, resistensi perifer meningkat, aliran darah ginjal dan laju filtrasi glomerulus yang menurun, aktifitas syaraf simpatis meningkat (Duthi \& Katz, 2007).

Terjadinya hipertensi pada lansia berawal dari disfungsi endotel akibat penuaan dimana produksi vasodilator sepertei Nitric Oxide (NO) dan Prostacyclin oleh sel endotel sudah sangat berkurang, NO diketahui sebagai vasodilator kuat dan memiliki peran penting dalam pengaturan agregasi platelet, ploriferasi otot polos serta adhesi leukosit (Men, 2011). Fenomena unik lain yang sering menjadi penyebab naiknya tekanan darah pada lansia adalah fenomena White-Coat Syndrome, yaitu fenomena dimana tekanan darah dapat naik secara signifikan karena terlalu peka terhadap perubahan lingkungan (Lerma, 2009). Menurut Aronow (2011) faktor ekternal hipertensi pada lansia yaitu diantaranya obesitas, merokok, konsumsi alkohol dan kurangnya olahraga. Obesitas sering dikaitkan dengan perubahan struktur dari jantung, pembuluh darah dan ginjal yang kemungkinan menjadi pemicu utama penyakit kardiovaskular dan ginjal. Merokok banyak sekali memiliki hubungan kompleks dengan hipertensi yang mana dapat menigkatkan risiko penyakit kardiovaskular, stroke, penyakit ginjal pada seluruh level tekanan darah. Merokok dapat meningkatkan kerusakan sel dengan meningkatkan aktifitas saraf simpatis, meningkatakan agregasi dan aktivitas platelet, meningkatkan radikal bebas, kerusakan endotel dan peningkatan tekanan arteri.

Stres fisik maupun non fisik diketahui memicu hipotalamus dalam memberikan stimulus simpatis pada medula adrenal untuk mensistesis hormon katekolamin. Hormon katekolamin memiliki peran sangat banyak terutama vasokontriksi pembuluh darah dan meningkatkan detak jantung, selain itu efek vasokontriksi hormon katekolamin di ginjal, tepatnya pada arteriol eferen ginjal juga berakibat pada menurunnya aliran darah yang kaya $\mathrm{O}_{2}$ keginjal sehingga akan merangsang sistem rennin angiotensis aldosteron yang secara bersama-sama akan meningkatkan volume plasma dengan meretensi garam dan $\mathrm{H}_{2} \mathrm{O}$ sehingga meningkatkan tekanan darah (Sherwood, 2007). Faktor lain terjadinya hipertensi pada lansia juga dipengaruhi oleh gaya hidup seperti kurang olahraga, kebiasaan merokok dan minum alkohol, obesitas, kurang konsumsi buah dan sayuran, tingginya konsumsi garam (Aronow, 2011).

Peningkatan tekanan darah pada lansia juga sering dikaitkan dengan terjadinya gangguan tidur pada lansia. Normalnya saat tidur malam tekanan darah pada lansia turun cukup curam (dipping), tapi hal ini tidak terjadi pada lansia yang mengalami gangguan tidur dimana tekanan darah mereka cenderung untuk tetap atau hanya sedikit turun (non-dipping), hal ini akan berpengaruh pada tekanan darah keesokan harinya yang cenderung untuk tinggi. Telah diketahui fenomena ini sering dikaitkan dengan pusat pengatur irama sirkadian yang terletak pada nucleus suprachiasmatik pada hipotalamus anterior yang fungsinya sudah mulai terbatas pada lansia dimana produksi hormon melatonin mulai menurun sehingga akan mengganggu 
irama simpatis maupun parasimpatis dalam pengaturan tekanan darah (Schachter, 2004).

Banyak sekali studi klinis yang membuktikan bahwa dengan menurunnya tekanan darah sisitolik dapat mencegah mortalitas dan morbiditas pada lansia. Menurunnya tekanan darah sistolik sebesar $10 \mathrm{mmHg}$ berhubungan dengan semakin berkurangnya $13 \%$ dari total kematian, $30 \%$ risikostroke, $28 \%$ kematian akibat penyakit kardiovaskular dan 23\% akibat penyakit koroner (Duthie \& Katz, 2007). Pemberian terapi antihipertensi pada lansia dalam menurunkan tekanan darah harus sesuai dengan kaidah dari JNC VII yaitu "start low go slow" dimana target penurunan tekanan darah adalah 140/90 $\mathrm{mmHg}$ dengan penurunan rerata secara bertahap antara 7-10 mmHg (Duthie \& Katz, 2007). Studi longitudinal The Farmingham Study di Amerika telah menemukan orang-orang umur paruh baya dengan hipertensi secara signifikan memiliki tingkat kecemasan diatas rata-rata dibandingkan orang-orang dengan normotensi, peneliti ini menyarankan bahwa terapi relaksasi dan perilaku menjadi terapi paling efektif untuk populasi orang-orang paruh baya dengan hipertensi akibat kecemasan (Olney, 2005).

Back massage merupakan salah satu jenis terapi komplementer yang telah terbukti dapat memberikan efek relaksasi dan menurunkan tekanan darah pada penderita hipertensi dengan penurunan tekanan darah rata-rata sekitar 10,8 $\mathrm{mmHg}$ (Olney, 2005). Back massage yang dikombinasikan dengan komunikasi terapeutik dan diberikan 5 kali selama 5 hari dalam waktu 30 menit setiap harinya memiliki efek penurunan tekanan darah melalui peningkatan vasodilatasi pembuluh darah dan mengurangi sekresi hormon stres sehingga berakibat pada penurunan tekanan darah (Hernandez, 2000).

Berdasarkan hasil yang diperoleh dari penelitian yang telah dilakukan di UPT PSLU Blitar didapatkan adanya penurunan tekanan darah sistolik dan tekanan darah diastolik sebagian besar lansia dari kelompok 1 maupun kelompok 2. Terdapat 1 lansia dari kelompok 1 yaitu responden no.1 yang bernama Tn. S justru mengalami peningkatan tekanan darah sistolik sebesar $5 \mathrm{mmHg}$ setelah pemberian communication back massage selama 5 hari, telah diketahui beliau berjenis kelamin laki-laki dan berusia 68 tahun. Tn. S sudah 8 bulan tinggal di UPT PSLU Blitar. Dilihat dari pola penurunan tekanan darah sistolik Tn. S pada lampiran 9 dapat diketahui bahwa terjadi penurunan tekanan darah sistolik yang signifikan sampai hari ke-2 perlakuan yaitu pada nilai 150 $\mathrm{mmHg}$, turun sebanyak $10 \mathrm{mmHg}$ dibandingkan tekanan darah sistolik pre test pada hari pertama yaitu $160 \mathrm{mmHg}$, setelah itu tekanan darah Tn. S kembali naik sampai hari ke-4 yang justru lebih tinggi daripada tekanan darah pre test yaitu $170 \mathrm{mmHg}$ dan pada hari terakhir perlakuan yaitu hari ke-5 tekanan darah beliau sedikit menurun sebesar $5 \mathrm{mmHg}$ menjadi $165 \mathrm{mmHg}$. Jika dilihat dari kriteria JNC VII maka Tn. S termasuk hipertensi stage 2 dengan kriteria tekanan darah sistolik $\geq 160 \mathrm{mmHg}$ dan tekanan darah diastolic $\geq 100 \mathrm{mmHg}$. Dapat diketahui bahwa selisih peningkatan tekanan darah pre test pada hari pertama dan post test pada hari kelima Tn. S adalah $5 \mathrm{mmHg}$.

Terdapat 1 lansia (responden no. 4) yang bernama Ny. P mengalami penurunan tekanan darah paling tinggi diantara lansia yang lain yaitu sebesar $28 \mathrm{mmHg}$ setelah pemberian communication back massage selama 5 hari. Ny. P diketahui berjenis kelamin perempuan dan berusia 64 tahun. Ny. P sudah 1 tahun tinggal di UPT PSLU Blitar. Dilihat dari pola penurunan tekanan darah sistolik Ny. P pada lampiran 9 dapat diketahui bahwa tekanan darah pre test beliau adalah $180 \mathrm{mmHg}$ dan terjadi penurunan tekanan darah sistolik yang signifikan pada hari pertama perlakuan yaitu sebesar 10 $\mathrm{mmHg}$ menjadi $170 \mathrm{mmHg}$ dan cenderung tetap pada angka yang sama sampai hari ke-3 yaitu antara 170-173 mmHg. Pada hari ke-4 tekanan darah responden tersebut kembali turun sebesar $5 \mathrm{mmHg}$ menjadi $165 \mathrm{mmHg}$ dan pada hari terakhir perlakuan tekanan darah sistolik Ny. P turun kembali sebesar 13 $\mathrm{mmHg}$ menjadi $152 \mathrm{mmHg}$. Jika dilihat dari kriteria JNC VII maka Ny. P termasuk hipertensi stage 1 dengan kriteria tekanan darah sistolik antara 141-159 $\mathrm{mmHg}$ dan tekanan darah diastolik 90-99 mmHg. Dapat diketahui bahwa selisih penurunan tekanan darah pre test pada hari pertama dan post test pada hari kelima $\mathrm{Ny}$. P adalah $28 \mathrm{mmHg}$. Analisis data menggunakan uji statistik Paired t-test pada kelompok 1 menunjukkan bahwa ada perbedaan tekanan darah sistolik pada lansia sebelum dan sesudah pemberian 
communication back massage, sedangkan untuk tekanan diastolik tidak ada perbedaan yang signifikan. Hasil analisis data menggunakan uji Independent t-test antara kelompok 1 dan kelompok 2 menunjukkan bahwa tidak ada perbedaan penurunan tekanan, hal ini juga sama terjadi pada tekanan darah diastolik. Rerata penurunan tekanan darah sistolik kelompok 1 lebih besar dari rerata penurunan tekanan darah sisitolik kelompok 2. Perbandingan penurunan rerata tekanan darah diastolik kelompok 1 memiliki rerata yang sama dengan kelompok 2 .

Dalam paradigma back massage tubuh manusia dianggap sebagai satukesatuan utuh dimana setiap sel dalam tubuh dapat saling berkomunikasi dan saling mempengaruhi satu sama lain (Myers, 2009). Kemampuan sel untuk saling berkomunikasi dan mempengaruhi satu sama lain tidak lepas dari adanya jaringan penyambung atau connective tissue yang dalam dunia masase dikenal sebagai myofascialfascia (Myers, 2009). Beberapa contoh dari jaringan penghubung yaitu kolagen, elastin, serabut retikulin, glikosaminoglikan, proteoglikan dan ground substance dimana kesemuanya tersebar dalam setiap bagian tubuh dan memiliki peran penting terhadap mekanisme fisiologis dari masase karena sifat dua kutubnya (Myers, 2009).

Tekanan mekanis dari back massage akan menstimulasi terbentuknya peizeoelectric effect yang membantu melonggarkan, merenggangkan dan memperpanjang serabut otot sehingga dengan adanya proses perenggangan otot ini maka akan meningkatkan sirkulasi darah dan membawa kembali $\mathrm{O}_{2}$ serta nutrisi kembali ke area tubuh yang tegang (Turkhaninov, 2003). Efek perenggangan otot polos ini juga terjadi pada arteri vertebra yang cenderung vasokontriksi pada lansia sehingga sirkulasi darah menuju medulla spinalis kembali normal yang berakibat pada penurunan tekanan darah secara fisiologis (Prilutsky, 2003). Kembalinya sirkulasi darah juga akan mengurangi nyeri otot akibat $\mathrm{pH}$ asam yang ditimbulkan oleh timbunan asam laktat sehingga sensitifitas reseptor ASIC3 (AcidSensing Ion Channel Number 3) menurun dan menimbulkan perasaan tenang, rileks dan lebih baik (Naves, 2005; Molliver, 2005). Mekanisme timbulnya perasaan tenang dan rileks ini selanjutnya juga diinduksi oleh menurunnya aktifitas gelombang $\alpha$ dan $\beta$ serta meningkatnya aktifitas gelombang $\delta$ pada SSP saat dan setelah pemberian back massage, perlu diketahui bahwa gelombang $\delta$ adalah gelombang otak yang secara normal muncul saat seseorang telah tertidur (Diego, 2004). Efek relaksasi melalui penurunan sekresi hormon katekolamin akan berlanjut pada penurunan aktifitas saraf simpatis disertai penurunan tekanan darah. Rasa enak dan nyaman akan tercapai sehingga secara psikis memberikan dampak positif bagi rasa tenang, nyaman, rileks, dan stres yang menurun. Respons positif ini melalui jalur HPA Aksis akan merangsang hipotalamus dan Locus Coerulus (LC). Hipotalamus akan menurunkan sekresi Corticotropin Releasing Hormone (CRH) Adrenocorticotropic Hormone sehingga (ACTH) menurun dan merangsang Pro-opimelanocortin (POMC) yang juga akan menurunkan produksi ACTH dan menstimulasi produksi endorphin. LC yang bertanggung jawab untuk menengahi banyak efek simpatik selama stres, dalam keadaan rileks akan menurunkan sintesis norepinefrin di medulla adrenal yang akan merangsang penurunan AVP (arginine vasopressin). Penurunan AVP dan ACTH serta peningkatan endorphin akan menurunkan tahanan perifer dan cardiac output sehingga tekanan darah akan menurun (Reyes, 2006; Valentino, 2008).

Terdapat 5 responden yang mengalami penurunan tekanan darah antara 8-20 mmHg mungkin disebabkan karena begitu mudahnya ketiga responden ini mencapai fase relaksasi saat diberikan back massage, contohnya adalah responden no. 2 yang bernama Tn. B mengalami penurunan tekanan darah sistolik sebesar $20 \mathrm{mmHg}$. Dari pengamatan peneliti telah diketahui bahwa Tn. B selalu tertidur saat dilakukan masase, hal ini dikarenakan back massage dapat memicu menurunnya aktifitas gelombang $\alpha$ dan $\beta$ serta meningkatnya aktifitas gelombang $\delta$ pada SSP sehingga memberikan efek relaksasi yang berdampak pada penurunan berbagai macam hormon stress yang berakibat pada penurunan tekanan darah. Dari komunikasi terapeutik telah diketahui bahwa kelima responden ini cenderung mempunyai sifat pasrah dan lapang dada sehingga mungkin berhubungan dengan paparan stres yang tidak terlalu tinggi. 


\section{SIMPULAN DAN SARAN}

\section{Simpulan}

Communication back massage dan back massage terbukti dapat menurunkan tekanan darah sistolik dan diastolik pada lanjut usia dengan hipertensi. Communication back massage dan back massage mempunyai efek relaksasi yang dapat menurunkan skresi noreepinefrin dan ADH, serta meningkatkan sekresi endorphin. Kesemua efek ini akan memiliki manfaat dalam penurunan tekanan darah pada lansia. Tidak ada perbedaan yang signifikan antara communication back massage dan back massage dalam menurunkan tekanan darah.

\section{Saran}

Pada penelitian selanjutnya diharapkan tidak sebatas hanya mengukur penurunan tekanan darah saja, tetapi disarankan untuk mengukur secara infitro kadar ACTH responden. Pada penelitian selanjutnya diharapkan peneliti lebih meminimalkan variabel perancu seperti merokok, konsumsi garam berlebih dan konsumsi kafein agar hasil penelitian ini lebih signifikan.

\section{KEPUSTAKAAN}

Aronow, WS 2011, A report of the American college of cardiology foundation task force on clinical expert on consensus documents, ACCF/AHA 2011 Expert Consensus Document on Hypertension in the Elderly April 2011, Elsevier, USA Hal. 11-55.

Duthie, EH \& Katz, PR 2007, Practice of Geriatric, edisi 4, WB Saunders Company USA, Hal. 429-436.

Hernandez, M 2000, High blood pressure and associated symptoms were reduced by massage therapy, Journal of Bodywork and Movement Therapies, Vol. 4, No.1, Hal. 31-38.

Lerma, E 2009, Current Diagnosis \& Treatment: Nephrology \& Hypertension, McGraw Hill, USA 353-382.

Molliver, DC 2005, ASIC3, an acid-sensing ion channel, is expressed in metaboreceptive sensory neurons,
Molecular Pain, vol.1, hal.35 (http://www.molecularpain.com/conte $\mathrm{nt} / 1 / 1 / 35)$

Myers, T 2009, Anatomy Trains, Edisi 2, Churchill Livingstone Elsevier, London, Hal. 18-94.

Naves, LA \& McCleskey, EW 2005, An acid-sensing ion channel that detect ischemic pain, Brazilian Journal of Medical and Biological Research, Vol. 38, Hal. 1561-1569

Olney, CM 2005, The effect of therapeutic back massage in hypertensive persons: A preliminary study, Biological Research For Nursing, Vol. 7, No. 2, Hal. 98-105.

Prilutsky, B 2003, Medical massage and control of arterial hypertension: $A$ pilot study, Massage \& Bodywork. Diakses $22 \quad$ Maret 2012,(http://www.massageandbodywo rk.com/Articles/AugSep2003/Medical massage.html).

Reyes, BAS 2006, Pro-opiomelanocortin colocalizes with corticotrophinreleasing factor in axon terminals of the noradrenergic nucleus locus coeruleus. European Journal of Neuroscience, Vol. 23, No. 3, Hal 2067-2077.

Riaz, A 2010, What are frequent sign and symptom of isolated systolic high blood pressure, Diakses 02 April 2012 dari http://www.lifemeanshealth.com/hea lth-articles/hypertension/what-arefrequent-signs-and-symptoms-ofisolated-systolic-high-bloodpressure.html

Sandhu, RG 2011, Defining the role of communication: IPSB massage therapy center, Diakses 05 Agustus 2012, dari http://www.ipsbmassagetherapy.com /news-articles/defining-the-role-ofcommunication

Schachter, M 2004, Diurnal rhythm, the rennin-angiotensin system and antihypertensive therapy, Diakses 25 Maret 2012, dari http://www.medscape.com/viewartic le/490535

Sherwood, L 2007, Fisiologi Manusia: Dari Sel ke Sistem, EGC, Jakarta Hal. 297-776. 
Soejono, CH 2003, 'Hipertensi sistolik terisolasi di Indonesia, prevalensi dan faktor resiko', Tesis, tidak dipublikasikan, Universitas Indonesia, Jakarta.

Timiras, PS 2007, Physiological Basis of Aging and Geriatrics, edisi 4, Informa Health Care, New York Hal. 219-240.

Turchaninov, R 2003, Research \& massage therapy, part 2: Why does massage benefite the body?, Diakses

8 April 2012, dari

http://www.massagetherapy.com/arti cles/index.php/article_id/236/Resear ch--Massage-Therapy-Part-2

Valentino, RJ 2008, Convergen regulation of locus coeruleus activity as an adaptive response to stress, European Journal of Pharmacology, Vol. 583, Hal. 194-203. 